Key Words:

Thermal Correlations

CSSX

Retention: Permanent

\title{
ESTIMATION OF THE TEMPERATURE RISE OF A MCU ACID STREAM PIPE IN NEAR PROXIMITY TO A SLUDGE STREAM PIPE
}

F. F. Fondeur

M. R. Poirier

S. D. Fink

July 12,2007

Washington Savannah River Company

Savannah River Site

Aiken, SC 29808

Prepared for the U. S. Department of Energy Under

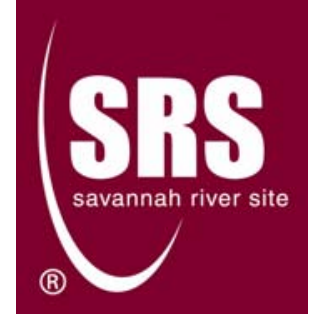

Contract Number DE-AC09-96SR18500 


\section{DISCLAIMER}

This report was prepared by Washington Savannah River Company (WSRC) for the United States Department of Energy under Contract No. DE-AC09-96SR18500 and is an account of work performed under that contract. Neither the United States Department of Energy, nor WSRC, nor any of their employees makes any warranty, expressed or implied, or assumes any legal liability or responsibility for the accuracy, completeness, or usefulness, of any information, apparatus, or product or process disclosed herein or represents that its use will not infringe privately owned rights. Reference herein to any specific commercial product, process, or service by trademark, name, manufacturer or otherwise does not necessarily constitute or imply endorsement, recommendation, or favoring of same by WSRC or by the United States Government or any agency thereof. The views and opinions of the authors expressed herein do not necessarily state or reflect those of the United States Government or any agency thereof.

Printed in the United States of America

Prepared For

U.S. Department of Energy 


\section{AUTHORS}

\section{REVIEWS AND APPROVALS}

\begin{tabular}{ll}
\hline F. F. Fondeur, author, Separations Science Programs & Date
\end{tabular}

\begin{tabular}{ll}
\hline M. R. Poirier, coauthor, Separations Science Programs & Date
\end{tabular}

S. D. Fink, coauthor and Manager, Separations Science Programs Date

DESIGN CHECK (per Manual E7, Procedure 2.40)

C. A. Nash, Separations Science Programs

Date

\section{APPROVALS}

A. M. Murray, Manager, Actinide and Chemical Science and Technology Date

W. L. Isom, Jr., Manager, Salt Engineering Date

G. C. Arthur, LW Process Engineering Date

\begin{tabular}{ll}
\hline C. L. Atseff, Manager, LW Process Engineering Date &
\end{tabular} 


\section{ACRONYMS}

\begin{tabular}{|l|l|}
\hline CLFL & composite lower flammability limit \\
\hline CSSX & Caustic-Side Solvent Extraction \\
\hline DSS & Decontaminated Salt Solution \\
\hline DWPF & Defense Waste Processing Facility \\
\hline MCU & Modular Caustic Side Solvent Extraction Unit \\
\hline SE & Strip Effluent \\
\hline SRS & Savannah River Site \\
\hline SWPF & Salt Waste Processing Facility \\
\hline WSRC & Washington Savannah River Company \\
\hline A & surface area \\
\hline$c_{p}$ & heat capacity \\
\hline C $m a x$ or min & C x mass flow rate \\
\hline D & diameter \\
\hline F & view factor \\
\hline h & heat transfer coefficient \\
\hline H & distance from center of buried pipe to soil-air interface \\
\hline ID & inner diameter \\
\hline k & thermal conductivity \\
\hline m & mass \\
\hline Nu & Nusselt number \\
\hline Pr & Prandlt number \\
\hline q, Q & heat flux \\
\hline R & Resistance \\
\hline Ra & Rayleigh number \\
\hline S & distance between pipes \\
\hline t & time \\
\hline T & temperature (Kelvin) \\
\hline U & overall heat transfer coefficient \\
\hline$\alpha$ & thermal diffusivity \\
\hline
\end{tabular}


WSRC-STI-2007-00276

PAGE 5 OF 17

\begin{tabular}{|l|l|}
\hline$\varepsilon$ & emissivity \\
\hline$v$ & kinematic viscosity \\
\hline$\Theta$ & $\begin{array}{l}\text { Difference between the temperature of the pipe raised to the fourth } \\
\text { power and the temperature of the air inside the jacket raised to the } \\
\text { fourth power }\end{array}$ \\
\hline$\pi$ & 3.1417 \\
\hline$\sigma$ & Stefan-Boltzmann coefficient \\
\hline$\infty$ & Infinite (air between core pipes and jacket) \\
\hline
\end{tabular}




\section{EXECUTIVE SUMMARY}

Effluent streams from the Modular Caustic-Side Solvent Extraction Unit (MCU) will transfer to the tank farms and to the Defense Waste Processing Facility (DWPF). These streams will contain entrained solvent. A significant portion of the Strip Effluent (SE) pipeline (i.e., acid stream containing Isopar ${ }^{\mathbb{B}} \mathrm{L}$ residues) length is within one inch of a sludge stream. Personnel envisioned the sludge stream temperature may reach $100{ }^{\circ} \mathrm{C}$ during operation. The nearby SE stream may receive heat from the sludge stream and reach temperatures that may lead to flammability issues once the contents of the SE stream discharge into a larger reservoir. To this end, personnel used correlations from the literature to estimate the maximum temperature rise the SE stream may experience if the nearby sludge stream reaches boiling temperature.

Several calculation methods were used to determine the temperature rise of the SE stream. One method considered a heat balance equation under steady state that employed correlation functions to estimate heat transfer rate. This method showed the maximum temperature of the acid stream (SE) may exceed $45^{\circ} \mathrm{C}$ when the nearby sludge stream is $80{ }^{\circ} \mathrm{C}$ or higher. A second method used an effectiveness calculation used to predict the heat transfer rate in single pass heat exchanger. By envisioning the acid and sludge pipes as a parallel flow pipe-to-pipe heat exchanger, this method provides a conservative estimation of the maximum temperature rise. Assuming the contact area (i.e., the area over which the heat transfer occurs) is the whole pipe area, the results found by this method nearly matched the results found with the previous calculation method. It is recommended that the sludge stream be maintained below $80{ }^{\circ} \mathrm{C}$ to minimize a flammable vapor hazard from occurring. 


\section{INTRODUCTION}

The Department of Energy identified the Caustic-Side Solvent Extraction (CSSX) process as the preferred technology to remove cesium from radioactive waste solutions at the Savannah River Site (SRS). ${ }^{1,2}$ As a result, Washington Savannah River Company (WSRC) began designing and building a Modular CSSX Unit (MCU) in the SRS tank farm to process liquid waste for an interim period until the Salt Waste Processing Facility (SWPF) begins operations. Both the MCU and SWPF use the CSSX technology although the facilities differ in size and processing rate.

The solvent extraction process generates two product streams: the decontaminated salt solution (DSS) depleted in radioactive cesium, and the strip effluent (SE) containing the bulk of the radioactive cesium removed from the waste. These streams pass through coalescers and decanters to remove suspended solvent droplets, reducing the mass of solvent transferred to downstream facilities. The recovered solvent becomes available for reuse in the solvent extraction processes. The DSS stream transfers to Tank $50 \mathrm{H}$ and from Tank $50 \mathrm{H}$ to Saltstone. The SE stream transfers to the Defense Waste Processing Facility where the radioactive cesium is vitrified with sludge waste.

On its way to the DWPF facility, the SE stream will share more than 1158.6 meters of distance with a pipe line containing sludge. Over about 579 meters of distance, the SE stream pipe will be above the sludge stream pipe and for the remaining distance the SE stream pipe will be below the sludge pipe. The SE stream will be within one inch of the sludge stream pipe (see Figure 1). The inner pipes are slightly eccentric relative to the Jacket (larger jacket inner diameter, ID, used for calculations). The SE streams may contain Isopar $^{\circledR} \mathrm{L}$, a volatile and flammable component. Personnel envisioned the sludge stream temperature may reach $100^{\circ} \mathrm{C}$. One possible accident scenario is the heat transfer from the sludge stream pipe (at $100{ }^{\circ} \mathrm{C}$ ) to the SE stream pipe raising its temperature to a range where the volatile component vapor pressure may be significant.

For a conservative and bounding case, it was assumed the SE stream pipe remains above the sludge stream pipe for the entire length (1158.6 meters). In addition, all calculations here are steady state and conservatively omit transfer line heating. (Ignoring the heat capacity, or heating, of the pipe mass maximizes the calculated energy transferred to the SE stream.)

Several calculations with different assumptions were performed to estimate the sludge temperature drop and the acid stream exiting temperature. Heat transfer calculations included: (1) a single sludge pipe inside the jacket pipe, (2) an isothermal sludge heating an acid pipe, (3) a single pass heat exchanger between sludge pipe and acid pipe, and (4) a heat transfer between the sludge and acid pipe accounting for heat transfer resistances and allowing the sludge pipe and acid pipe temperature to vary.

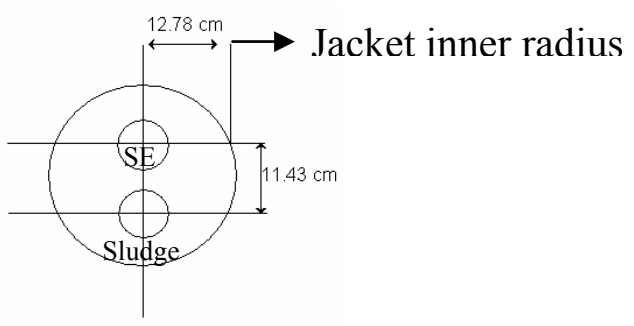

Figure 1. Spatial arrangement of the pipes 


\section{RESULTS}

\section{Single Sludge Pipe in a Jacket}

Assuming a single sludge pipe in a jacket pipe, personnel calculated the temperature drop the sludge pipe will experience when the soil surface temperature is $26.7^{\circ} \mathrm{C}$ (i.e., the average maximum temperature experienced at SRS during the summer season). ${ }^{3}$ The SE pipe is not present (and not removing heat) in this calculation. The calculation uses the driving force over resistance approach to estimate temperature drops. The calculation assumes the soil temperature does not vary significantly as the sludge is transported through the jacket pipe, and the resistance is constant and independent of the temperature difference between the sludge and the jacket pipe temperature. Another assumption used (and confirmed by the calculation) is that the temperature of the sludge pipe metal is the same as the temperature of the sludge slurry in the pipe (i.e., resistance from forced convective heat transfer within the sludge pipe is negligible due to the high flow rate). In addition, the calculation assumes the jacket temperature does not vary along the length of the pipe. The overall resistance between the sludge pipe and the soil is shown in Figure 2.

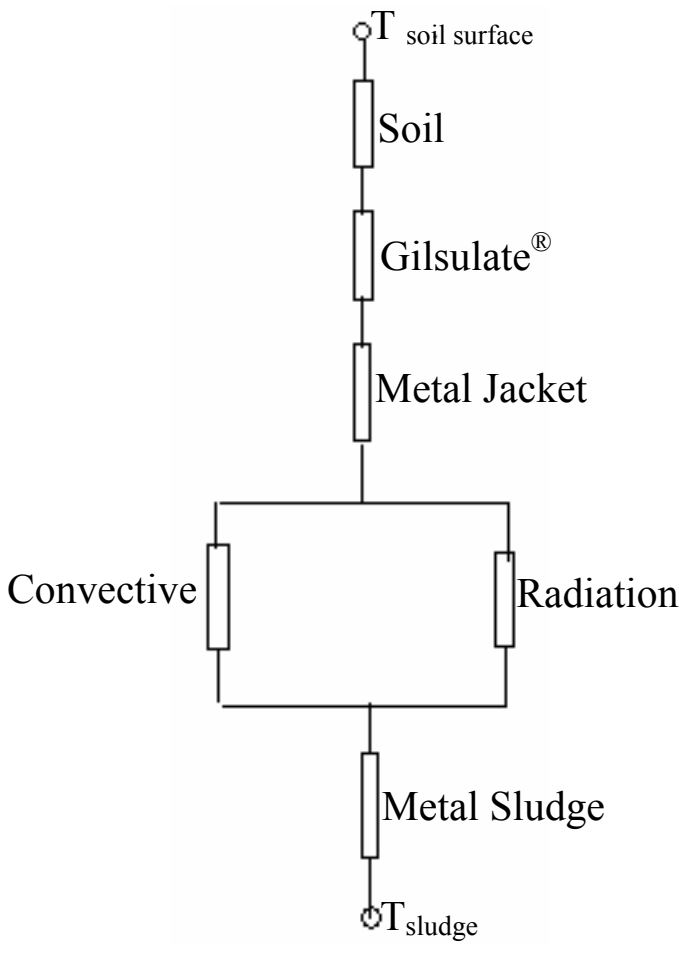

Figure 2. An illustration of the path resistance to heat transfer from the sludge pipe to the soil surface. 
We used equations 1 (omitting the sludge to acid heat transfer), 4, 5, 6, and 7 to calculate the individual resistance elements (or components) to heat transfer. We then calculated the driving force for heat transfer given by the log mean difference between the temperature of the sludge and the soil surface along the whole length of the pipe. Using the iteration procedure "Solver" from Excel software, we determined the temperature drop of the sludge stream as it travels down the pipeline. Table 1 shows the result from this effort. The temperature drop is less than $1{ }^{\circ} \mathrm{C}$ due to the high sludge flow rate and high resistance to heat losses. The temperature drop is consistent with the expectation that the air gap between the sludge and jacket pipes as well as the resistance of the Gilsulate $^{\circledR}$-soil interface is sufficient to maintain an insulating environment around the sludge pipe.

Table 1. The sludge pipe temperature drop when there is no acid pipe flow within the jacket pipe.

\begin{tabular}{|c|c|}
\hline Sludge Inlet Temperature $\left({ }^{\circ} \mathrm{C}\right)$ & Sludge Outlet Temperature $\left({ }^{\circ} \mathrm{C}\right)$ \\
\hline 100 & 99.4 \\
\hline 80 & 79.6 \\
\hline 60 & 59.7 \\
\hline 40 & 39.9 \\
\hline
\end{tabular}

\section{Equations and Inputs for More Complex Configurations}

To determine the temperature rise of the SE stream, we next determined the extreme temperature the stream can reach in the case where the sludge pipe temperature is kept isothermal in the presence of the jacket pipe. In these calculations the sludge pipe is assumed isothermal at selected temperatures of 100, 80, 60 and $40{ }^{\circ} \mathrm{C}$. Secondly, to verify the magnitude of the results found using this approach, we performed a calculation viewing the core pipes a parallel flow heat exchanger (in this case the Jacket pipe presents no heat sink). The final calculation allows for the sludge temperature to vary along its length as well as the driving force for heat transfer. Calculations used the parameters listed in Table 2 and from other sources. Note these numbers change with temperature (especially viscosity) and they were recalculated every time the temperature changed. We used the energy balances in equations 1 and 2 to calculate the heat transfer from the sludge pipe to the acid pipe and the soil.

$$
\frac{d q}{d t} \text { sludgeto soil }_{\text {sludgeto acid }}+\frac{d q}{d t} C_{p}\left(T_{\text {sludge }}^{\text {out }}-T_{\text {sludge }}^{\text {in }}\right)=\frac{\text { Curies }}{\text { gal }}_{\text {sludge }} \times \frac{k W a t t s}{C i} \times \text { pipe volume }
$$

$\frac{d m}{d t} C_{p}\left(T_{\text {acid }}^{\text {out }}-T_{\text {acid }}^{\text {in }}\right)=\frac{d q}{d t}_{\text {sludgeto acid }}+\frac{\text { Curies }}{g a l}_{\text {acid }} \times \frac{k \text { Watts }}{C i} \times$ pipe volume 
$Q=A \times \frac{\varepsilon\left(1-(1-\varepsilon) F^{2}\right) \sigma \Theta_{1}^{4}-\varepsilon^{2} F \sigma \Theta_{2}^{4}}{1-(1-\varepsilon)^{2} F^{2}}$

$\Theta_{1}^{4}=T_{W 1}^{4}-T_{\infty}^{4}, \Theta_{2}^{4}=T_{W 2}^{4}-T_{\infty}^{4}$

$F_{1-2}=\frac{2}{\pi}\left[\sin ^{-1}(D / S)+\left((S / D)^{2}-1\right)^{1 / 2}-(S / D)\right]$

$F_{1-\infty}=1-\alpha F_{1-2}, \alpha=1$ for top / bottom pipes, $\alpha=2$ for in - between pipes

$F_{1-2}=0.2638$

In equation 3, the symbol " $D$ " stand for the diameter of the pipe (in this case the core pipes), "S" stands for the distance between the pipe's center points, " $T_{w}$ " stands for the wall temperature, " $\mathrm{T}_{\infty}$ " stands for the air temperature away from the wall, and " $\mathrm{A}$ " stands for the pipe surface area (in this case is $323.6 \mathrm{~m}^{2}$ ). " $F$ " is the view factor between the sludge and acid pipes.

We used equation 4 to estimate the amount of heat absorbed by convection. The heat transfer coefficient used was the natural convection of heat from a heated pipe to air. ${ }^{5}$

$Q=h \times A \times\left(T_{\text {sludgewall }}-T_{\text {air }}\right)$

For calculating the convective heat transfer coefficient, equation 5 was used. We matched the heat received by the jacket pipe to the cooling by the exterior Gilsulate ${ }^{\circledR}$ insulation and soil while simultaneously matching the heat received by the acid pipe to the cooling provided by the flow of the acid. ${ }^{6}$

The jacket pipe receives heat from both convection and radiation. In equation 5 , the symbol " $D_{i}$ or o" stands for the diameter of the sludge (i) or jacket (o) pipe. The symbol "Ra" depicts the Raleigh's number based on either the diameter of the sludge pipe (i) or the diameter of the jacket pipe (o). The symbol " $\mathrm{k}$ " represents the thermal conductivity, " $h$ " stands for the convection heat transfer coefficient, " $T$ " stands for the wall temperature of either the sludge or jacket pipe, " $\alpha$ " equals for the thermal diffusivity of air (dependent on temperature) and " $v$ " identifies the kinematic viscosity (as a function of temperature).

The thermal radiation received by the jacket from the sludge pipe was calculated using equation 6 . In equation 6 , the symbol " $\sigma$ " is the Stefan-Boltzmann coefficient (5.67E-8 $\left.\mathrm{W} / \mathrm{m}^{2}{ }^{*} \mathrm{~K}^{4}\right)$ and " $\varepsilon$ " stands for the emissivity of iron ( 0.35 for polished steel). Soil cooling was calculated using equation 7 . In equation 7 , the " $H$ " stands for the distance from the surface of the soil to the center point of the buried pipe.

Iteration continued until the values found for the outlet acid pipe changed less than $0.5 \%$, the results obtained for the acid outlet temperature are shown in Table 3. Inspection of Table 3 shows that sludge temperatures higher than $80{ }^{\circ} \mathrm{C}$ may lead to flammable conditions in downstream tanks. The magnitude of heating for the acid is due to the proximity of the acid pipe (about one inch) to the sludge that captures nearly $30 \%$ of the 
WSRC-STI-2007-00276

PAGE 12 OF 17

thermal radiation emitted by the sludge. In addition, all the convective heat generated by the sludge pipe passes to the acid pipe in this calculation.

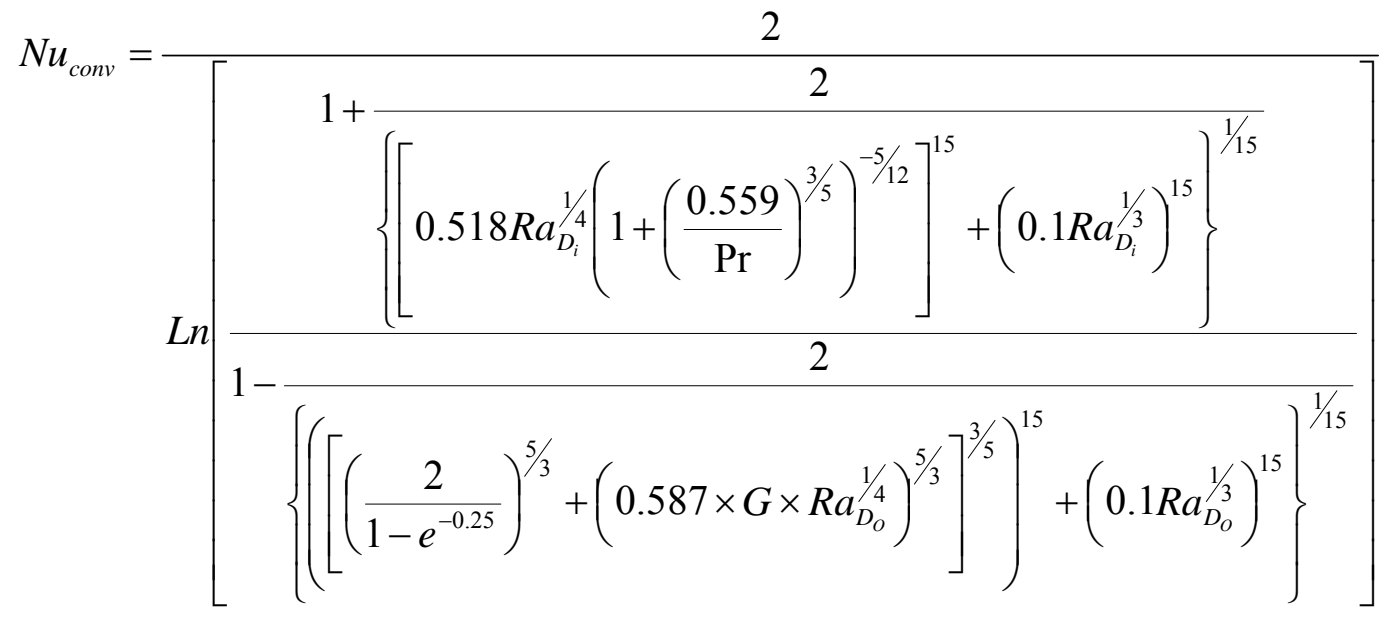

$G=\left[\left(1+\frac{0.6}{\operatorname{Pr}^{0.7}}\right)^{-5}+\left(0.4+2.6 \operatorname{Pr}^{0.7}\right)^{-5}\right]^{-1 / 5}$

$N u_{\text {conv }}=\frac{h \times D}{k}$

$q=N u_{\text {conv }} \times k \times \pi \times L \times\left(T_{D_{i}}-T_{D_{O}}\right)$

$R a_{D_{i, O}}=\frac{g \times \frac{\left(T_{D_{i}}-T_{D_{P}}\right)}{\left(\frac{T_{D_{i}}+T_{D_{P}}}{2}\right)} \times D_{\text {iorO }}^{3}}{v \times \alpha}$

$q_{\text {radiation }}=\frac{\sigma \times A_{\text {sludgepipe }} \times\left(T_{\text {sludgepipe }}^{4}-T_{\text {Jacketpipe }}^{4}\right)}{\frac{1}{\varepsilon}+\frac{A_{\text {sludgepipe }}}{A_{\text {jacketpipe }}} \times\left(\frac{1}{\varepsilon}-1\right)}$

$q=\frac{2 \pi L \times k}{\operatorname{Ln}(4 H / D)} \times\left(T_{\text {jacket }}-T_{\text {Surfce Soil Temperature }}\right)$ 


\begin{tabular}{|l|l|l|l|l|}
\hline $\begin{array}{l}\text { Table 3. The calculated acid stream temperature rise as a function of the } \\
\text { isothermal sludge temperature. }\end{array}$ & 80 & 60 & 40 \\
\hline $\begin{array}{l}\text { Inlet Sludge Temperature } \\
\left({ }^{\circ} \mathrm{C}\right) \text { (Constant) }\end{array}$ & 100 & 44.8 & 39.2 & 34.6 \\
\hline $\begin{array}{l}\text { Exiting Acid Temperature } \\
\left({ }^{\circ} \mathrm{C}\right) *\end{array}$ & 51.13 & 44.2 & 38.1 & 32.3 \\
\hline Jacket Temperature $\left({ }^{\circ} \mathrm{C}\right)$ & 50.6 & 48,540 & 25,616 & 6,678 \\
\hline $\begin{array}{l}\text { Power Added to Acid Pipe } \\
\text { (Watts) }\end{array}$ & 74,509 & & \\
\hline$*$ Assumes the entering acid temperature is $33^{\circ} \mathrm{C}$ & \\
\hline
\end{tabular}

\section{Single Pass heat Exchanger between Sludge and Acid Pipes}

To verify the results found in Table 3, calculations were performed viewing the core pipes as a single pass heat exchanger. For this purpose we used equation 8 for the calculation. In equation 8 , the term " $U$ " stand for the overall heat transfer.

$$
\begin{aligned}
& \varepsilon=\frac{1-\exp \left[\frac{-U A}{C_{\min }} \times\left(1+\frac{C_{\min }}{C_{\max }}\right)\right]}{1+\frac{C_{\text {min }}}{C_{\text {max }}}} ; C_{\text {min }}=\frac{d m_{\text {acid }}}{d t} \times C_{p_{\text {acid }}}, C_{\text {max }}=\frac{d m_{\text {sludge }}}{d t} \times C_{p_{\text {sludge }}} \quad 8 \\
& q=\varepsilon \times C_{\text {min }} \times\left(T_{\text {in }}^{\text {sludge }}-T_{\text {in }}^{\text {Acid }}\right)=C_{\text {acid }} \times\left(T_{\text {out }}^{\text {acid }}-T_{\text {in }}^{\text {acid }}\right)
\end{aligned}
$$

To use equation 8 , we assumed that the heat transfer area between the sludge pipe and acid pipe is the total surface area of the acid pipe. Table 4 shows the results. Inspection of Table 4 shows the outlet temperature rise of the acid nearly matches the results from Table 4. The discrepancy between the results shown in Tables 4 and 5 is due to the isothermal condition used in calculating Table 4 that does not allow for heat lost to the soil and, therefore, more heat is transferred to the acid pipe. 


\begin{tabular}{|c|c|c|}
\hline $\begin{array}{l}\text { Inlet Sludge Temperature } \\
\left({ }^{\circ} \mathrm{C}\right)\end{array}$ & $\begin{array}{l}\text { Acid Outlet Temperature } \\
\qquad\left({ }^{\circ} \mathrm{C}\right)\end{array}$ & $\begin{array}{l}\text { Power Added to the Acid } \\
\text { (W) }\end{array}$ \\
\hline 100 & 49 & 65,740 \\
\hline 80 & 43 & 43,173 \\
\hline 60 & 38 & 22,496 \\
\hline 40 & 34 & 4,837 \\
\hline
\end{tabular}

Accounting for Heat Transfer Resistance and (Longitudinal) Variance in Pipe Temperature

For a more realistic scenario, we also calculated the temperature rise of the acid pipe using thermal resistance calculations. In this approach, the heat given off by the sludge pipe is given to both the soil via the jacket pipe and to the acid pipe. The resistances between the sludge pipe and the soil surface (see Figure 3) were used to compute the portion of the heat lost to the soil. The portion of the heat given to the acid pipe was calculated using the resistance diagram shown in Figure 3. When the two heat transfer paths are combined, the overall heat transfer resistance for the SE stream line, the sludge stream, and the jacket pipe is shown in Figure 4. Inspection of Figure 4 shows an additional heat transfer (by radiation) between the jacket pipe and the SE stream pipe. The resistances were obtained from the inverse of equations 3-7. We allowed for the heat driving force to vary (decrease) along the length of the pipe by using log-mean driving forces (and variable resistance as well). Excel was used to iterate between the equations to determine heat losses to the soil and acid pipe. The results are shown in Table 5. In Table 5, the outlet sludge and acid temperatures are shown as well as the power received by the acid pipe during the transfer (assuming steady state). The presence of an additional heat sink (i.e., the metal pipe carrying the acid stream) with a smaller resistance draws more heat from the sludge pipe and the resulting increase in the acid stream temperature increases with the increasing temperature of the incoming sludge stream. To minimize volatility and flammability issues associated with organic entrained in the acid stream, the sludge temperature should be less than $80^{\circ} \mathrm{C}$ to avoid increasing the exiting acid temperature above $45^{\circ} \mathrm{C}$. If the sludge pipe is not completely full or sludge transfers are performed in sufficiently short periods of time such that steady state conditions are not achieved (due to thermal inertia), then it is possible to avoid heating the acid pipe above $40{ }^{\circ} \mathrm{C}$ even if the sludge is at $100{ }^{\circ} \mathrm{C}$. 


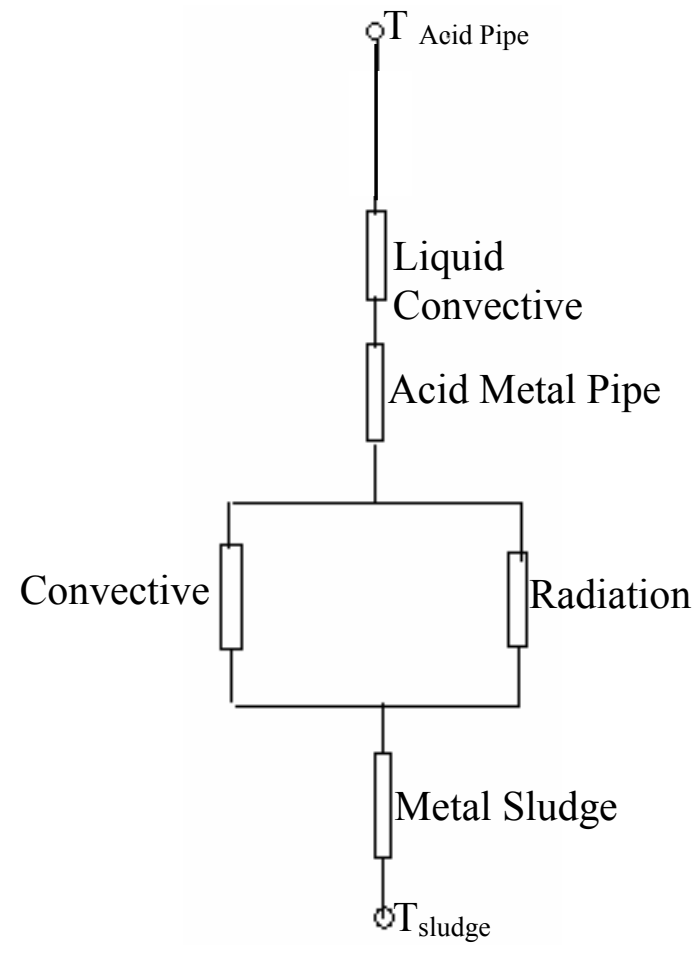

Figure 3. An illustration of the path resistance to heat transfer from the sludge pipe to the acid metal pipe.

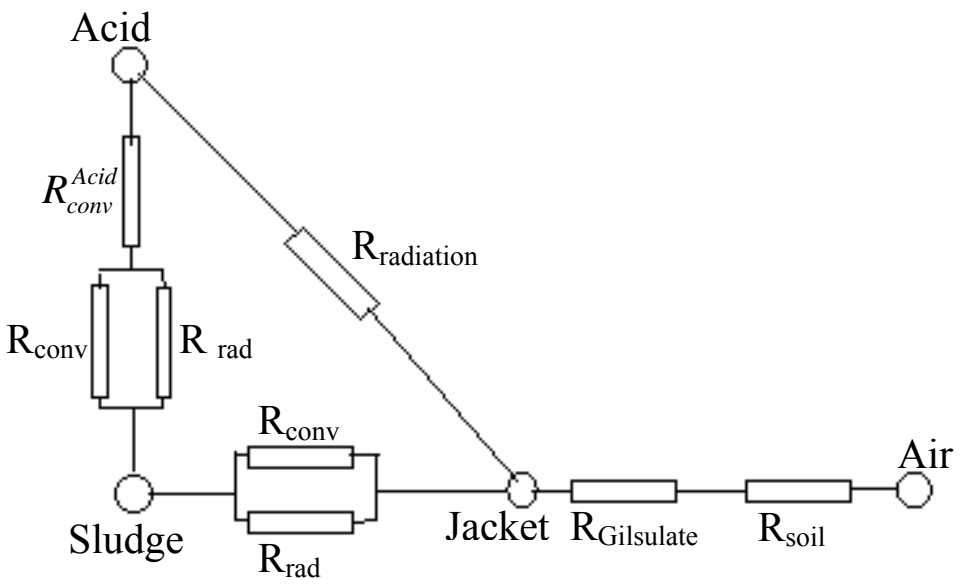

Figure 4. A schematic of the thermal resistance for heat dissipation from the sludge pipe to the soil and the acid pipe 


\begin{tabular}{|l|l|l|l|}
\hline $\begin{array}{l}\text { Table 5. The calculated acid stream outlet temperature using thermal resistance } \\
\text { calculation. This assumes the SE stream contains 80 Ci per gallon. }\end{array}$ \\
\hline $\begin{array}{l}\text { Inlet Sludge } \\
\text { Temperature }\left({ }^{\circ} \mathrm{C}\right)\end{array}$ & $\begin{array}{l}\text { Outlet Sludge } \\
\text { Temperature } \\
\left({ }^{\circ} \mathrm{C}\right)\end{array}$ & $\begin{array}{l}\text { Acid Outlet } \\
\text { Temperature }\left({ }^{\circ} \mathrm{C}\right)\end{array}$ & $\begin{array}{l}\text { Power Added to the } \\
\text { Acid }(\mathrm{W})\end{array}$ \\
\hline 100 & 97.5 & 47.5 & 59,700 \\
\hline 80 & 78.2 & 43.0 & 41,129 \\
\hline 60 & 59.1 & 38.3 & 21,804 \\
\hline 40 & 39.8 & 34.1 & 4,660 \\
\hline$*$ Assumes the acid inlet temperature is $33^{\circ} \mathrm{C}$ & \\
\hline
\end{tabular}

\section{CONCLUSION}

MCU plans to transfer an acid stream containing residues of Isopar ${ }^{\circledR}$ L to DWPF. The submerged transfer line is also accompanied by a sludge stream from Tank $40 \mathrm{H}$. Personnel envision the sludge line may reach temperatures of $100{ }^{\circ} \mathrm{C}$ and suspected that enough heat may transfer to the acid such that upon discharge in a closed (but with free gas volume) vessel the vapor space may reach flammable conditions. We performed calculations showing that the acid may reach temperatures in excess of $45{ }^{\circ} \mathrm{C}$ if the sludge line reaches a temperature higher than $80{ }^{\circ} \mathrm{C}$. Therefore, it is recommended the sludge line is maintained below $80^{\circ} \mathrm{C}$ to minimize this hazard scenario. 


\section{REFERENCES}

1 C. L. Huntoon to G. P. Rudy, memorandum titled "Preferred Alternative for the Savannah River Salt Processing Project", June 25, 2001.

2 R. A. Dimenna, H. H. Elder, J. R. Fowler, R. C. Fowler, M. V. Gregory, T. Hang, R. A. Jacobs, P. K. Paul, J. A. Pike, P. L. Rutland, F. G. Smith, III, S. G. Subosits, G. A. Taylor, S. E. Campbell and F. A. Washburn, "Bases, Assumptions, and Results of the Flowsheet Calculations for the Decision Phase Salt Disposition Alternatives", WSRCRP-99-00006, Rev. 3, May 24, 2001.

3 F. C. Sappington, M. A. Phifer, M. E. Denham, M. R. Millings, C. E. Turik, and P. C. McKinsey, "D-Area Sulfate Reduction Study Comprehensive Final Report(U)," WSRC-TR-2005-00017, WSRC, Aiken, SC, February 11, 2005.

4 E. M. Sparrow and J. E. Niethammer, "Effect of Vertical Separation Distance and Cylinder to Cylinder Temperature Imbalance on Natural Convection for a Pair of Horizontal Cylinders," Journal of Heat Transfer, Vol. 103, Nov. 1981, pp. 638-644.

5 C. J. Geankoplis, "Transport Processes and Unit Operations," Third edition, PTR Prentice Hall, 1993.

6 J. P. Holman, “Heat Transfer,” Fourth Edition, McGraw-Hill, 1976. 